\title{
触 New Disease Reports \\ First report of Pantoea ananatis causing grain discolouration and leaf blight of rice in Russia
}

M. Egorova ${ }^{1}$, E. Mazurin ${ }^{1}$ and A.N. Ignatov ${ }^{2,3 *}$

${ }^{1}$ Russian Center for Plant Quarantine - VNIIKR, Bykovo, Moscow region, 140150, Russia; ${ }^{2}$ Russian Institute of Phytopathology, Bolshie Vyazemy, Moscow region, 143050, Russia; ${ }^{3}$ Russian People's Friendship University, Moscow, 117198, Russia

*E-mail: an.ignatov@gmail.com

Received: 03 Nov 2014. Published: 15 Nov 2015. Keywords: Oryza sativa, emerging bacterial plant pathogen

Since August 2011, leaf blight of rice plants (Oryza sativa) and grain discoloration on harvested seeds were observed in commercial fields in Primorsky Krai (region) in the Far East of Russia. Initially, light, rusty, water-soaked lesions, which later turned brown, appeared on the plant lemma or palea. Many immature and lighter grains, some with bacterial yellow ooze were observed on panicles at harvest. For bacterial isolation, samples of 400 seeds of several locally produced seed stocks were surface sterilised in $0.7 \%$ sodium hypochlorite, incubated for 30 minutes at $25^{\circ} \mathrm{C}$ crushed and passed through a coarse filter. A sample of seed extract was placed onto yeast dextrose carbonate agar in Petri dishes in duplicates and incubated at $37 \pm 2^{\circ} \mathrm{C}$ for two days. Yellow colonies were sub-cultured and used for further identification.

The suspected pathogenic isolates were Gram-negative, facultative anaerobes. Physiological and biochemical characterisation confirmed that the strains belonged to the genus Pantoea. They were positive for $\beta$ galactosidase, produced acid from d-glucose, d-mannitol, d-melibiose, 1 arabinose, sucrose, meso-inositol, glycerol, d-sorbitol, amygdalin, and utilised citrate and tartrate. They were negative for reduction of nitrate to nitrite, production of hydrogen sulphide, urease, arginine dihydrolase, lysine decarboxylase, tryptophane deaminase, ornithine, and decarboxylase. A selection of 15 isolates from seeds of cv. 'Lugovoi' were further studied according to the procedures of Coplin \& Kado (2001). All isolates were motile, induced a hypersensitive reaction (HR) in tobacco plants (Nicotiana tabacum cv. Xanthi), and were oxidase negative. The 16S rRNA gene fragment was amplified using the primers 5'AGAGTTTGATCATGGCTCAG3' and 5'AAGGAGGTGATCCAACCGCA3' (Mondal et al., 2011). The nucleotide sequences of all 15 strains (GenBank Accession No. KT741001.1-KT741015.1) were 99\% identical to P. ananatis AIMST

\section{Po.15 (HQ683996.1).}

Pathogenicity was verified on pathogen-free Oryza sativa cv. 'Lugovoi' and onion (Allium cepa) cv. 'Bessonovski Eary' by infiltration of bacterial suspensions $\left(10^{5} \mathrm{cfu} / \mathrm{ml}\right)$. Controls were infiltrated with sterile tap water. Plants were kept after inoculation at $26 / 24^{\circ} \mathrm{C}$ (day/night) in a greenhouse. Symptoms were first detected two weeks after inoculation and in four weeks they resembled natural lesions (Fig. 1). Bacteria were re-isolated and compared to the original strains. BOXA-PCR fingerprints of the re-isolated bacteria and original strains were highly similar (Fig. 2). No lesions were observed on controls. Based on nearly complete $16 \mathrm{~S}$ rRNA sequencing data, pathogenicity, and biochemical tests, the bacteria were identified as $P$. ananatis. This is the first report of $P$. ananatis causing a disease of rice in Russia, although a similar disease has been reported in nearby regions of China (Yan et al., 2010).

\section{Acknowledgements}

This work was supported by the Russian Foundation for Basic Research 13-04-40104-H

\section{References}

Coplin DL, Kado CI, 2001. Pantoea. In: Schaad NW, Jones JB, Chun W, eds. Laboratory guide for identification of plant pathogenic bacteria. St. Paul, MI, USA: APS Press, 73-82.

Mondal KK, Mani C, Singh J, Kim JG, Mudgett MB, 2011. A new leaf blight of rice caused by Pantoea ananatis in India. Plant Disease $\mathbf{9 5}$ 1582-1583. http://dx.doi.org/10.1094/PDIS-06-11-0533

Yan H, Yu SH, Xie GL, Fang W, Su T, Li B, 2010. Grain discoloration of rice caused by Pantoea ananatis (synonym Erwinia uredovora) in China Plant Disease 94, 482. http://dx.doi.org/10.1094/PDIS-94-4-0482B

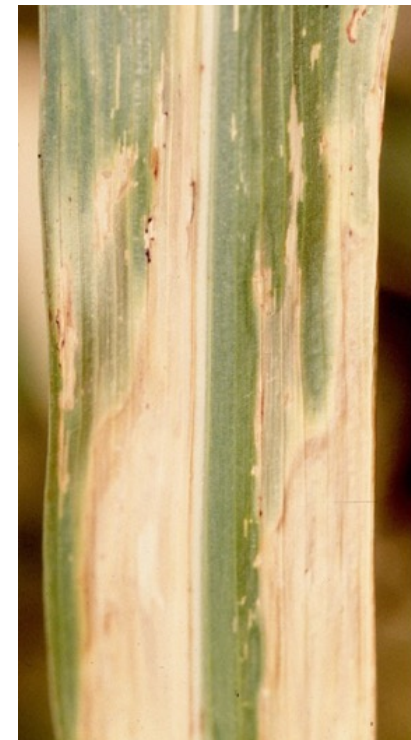

Figure 1

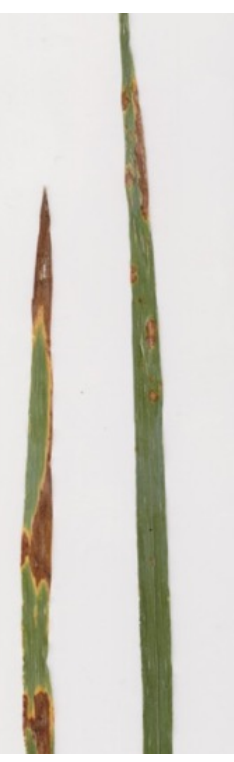

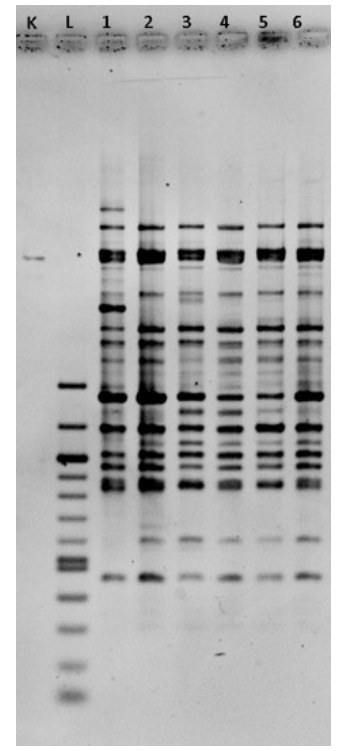

Figure 2

rice in Russia. New Disease Reports 32, 21. http://dx.doi.org/10.5197/j.2044-0588.2015.032.021

C 2015 The Authors

This report was published on-line at www.ndrs.org.uk where high quality versions of the figures can be found. 